\title{
Flexible workings: A valuable resource
}

\author{
Nazar Hussain, Sun Zehou, Muhammad Anwar ul Haq \\ Zafar-uz-Zaman Anjum \\ School of Management, Wuhan University of Technology, Wuhan, P.R. China
}

\begin{abstract}
The purpose of this paper is to analytically discuss the circumstances in which flexible workings become a valuable resource for a firm in the perspective of management consideration of human resource as most valuable resource for a firm. Paper integrates the different characteristics of human resources which make human resources the most valuable resource and flexible workings as most valuable for human resources. The greatest value a firm can give to its most valuable resource is flexible working options. There is no market more competitive than workforce market. There are many benefits of human resource and circumstances in which firm only relies on its human resource. The human resource turns a firm from failure to a success. These include quality of work, right work, better decision making, better business results, customer and owner satisfaction and a sustainable competitive advantage. This paper emphasizes the critical and important role of human resource for a firm and presents a resource based view of the firm. In most dynamic environments, the firms with best level of human resource possess higher capability in responding uncertain changes. Most valuable resource needs best policies. Such practices which are helpful in attracting, satisfying and retaining human resource are also a firm's valuable resource. It is argued that the benefits of flexible workings is valuable for organization. One can argue that human mind and abilities are most valuable firm resource. The policies and programs which satisfy and motivate the most valuable resource are also valuable firm resources. Paper represents an integrated model of relationships and benefits of flexible workings for employees, customers and shareholders. Paper concludes firms' sustainable growth is based on employee satisfaction, sustainable competitive advantage, customer, and shareholders satisfaction.
\end{abstract}

Keywords: Flexible workings, sustainable firm growth, employee satisfaction, work-life balance.

\section{INTRODUCTION}

A firm many resources at its disposal. Human resource is the only resource which improves a firm's efficiency and effectiveness. Human resource is the backbone for any organization. Employees influence the organizations and business processes. Employees are key for customers and owners satisfaction. Sustainable competitive advantage is based on sustainable human resource. These characteristics make human resource the most valuable firm resource. Effective human resource practices like training and development, empowerment, compensation and work life balance practices are very important for the success of any firm (Hong Chee EN et al., 2012).

Employee's satisfaction and retention is important in order to keep organization on right track. Employee's satisfaction and retention demands different effective human resource practices and programs from monetary to non-monetary benefits. Work life balance has become an important issue for employees and employers. An unbalanced life creates conflicts for both employer and employee. Developing such policies which create balance in the life of employees have become important for human resource professionals. Flexible workings arrangements are one of the common practices to balance work and life. Flexible workings have made organization's employees more efficient and focused when employees are at home or at work. These arrangements discourage the use of long working hours and provide base for employee empowerment. When flexible workings are implemented with the consent of employer and employee, these working practices increase efficiency, work focus and help to develop self-managed effective teams (Herneich, 2008).

Flexible workings like flextime, working nontraditional hours, home working, and working compressed working hours are examples of working desired hours and places. The Different flexible working systems are changing the working systems and patterns across the culture and time zones. Flexible workings are not practiced in any one country, in any particular industry and in any particular level, but a global phenomenon, across the countries, levels and industries (Jacobs, Gerson \& Gornick, 2004).

Flexible working arrangements also reflect the adoption of change in working patterns and market demand. The old working patterns may not be suitable for this and coming generations. Information and other technologies have changed old, rigid and inflexible workings systems. Adoption of these working arrangements is basically adoption of innovative workings ways. These innovative working ways reduces risk of stress and other mental and physical health risks. In this diverse work force flexible workings are commonly used to attract 
and retain the skilled employees. Retaining the desirable employees is most beneficial for any organization, since the human resource is not substitutable (Healthfield, M, 2005).

Flexible workings phenomena is the development of this century as prior to industrialization most workers were either farmers or self-employed. They decide themselves their workings schedules. They used to work as they wished. After industrialization and growing management awareness, the concept of getting activities to be completed among people increased. Labor markets costs, and increased technological use in working patterns forced the management to use and adopt the flexible workings patterns in their organizations.

General description of flexible workings is based on employee choice based scheduling. Usually, this is an agreed choice between employer and employee with the purpose to make work comfortable. It can be based on any arrangement may or may not be from common arrangements of flexible workings. This arrangement is based on how workers experience workings and managing other matters of the life. Flexible workings types are designed on this criteria: when, where, and how much one wants to work. These criteria can be used in combination. Organizations have practiced flexible workings informally and in many shapes. Now a days there is proper recognition and implementation of such policies.

\section{Human Resource And Flexible Workings}

New management and working patterns are arising all around the world as a result of social, economic, technological and political changes. Human resource have emerged as the most focal factor changing, because of change in these factors (Khusk, Fatma, 2001). Human resource is the most affected of these social and economic changes, globally. These social, economic and political changes demand the change in the working and motivation factors at workplaces. Organizations have to change their traditional working and motivation process, in order to meet changing demands of the world. Many companies are wasting their human capital; companies are not proper utilization and benefiting this resource for their organization and society. They are wasting most valuable resource; because they are not matching the work assignments with the workers' capabilities, interests and workers own interests in working time, interest, Quantity of the work and suitable place for work, etc. when employees are forced to do anything, may have interest or not and they are not allowed to solve their problems themselves; then employees are mentally separated from the organization and their work. This mental separation increases turnover intention and at the end results in physical separation.

Organizations bear huge turnover costs because of mismatch between the working environments and workers' interests. Performance and contribution of an employee starts decreasing on the day when mentally he does not feel himself part of the organization. These feelings arise when employees start thinking that their organization is not thinking about the employees but self-interests. Therefore, there is a need of creating right working environment at the workplace. The comfortable working environment includes many things like matching of the capabilities with work, allowing employees to meet their own goals in their work and organizational goals, implementation of such policies like flexible workings arrangements, which are liked and demanded by the employees. Before formulation and implementation of any policy regarding employees, their concerns must be addressed, in order to make policy more effective and objective oriented. Today, many organizations are claiming that their people are their strength and competitive advantage for their organization. But many companies have failed in unleashing their people power and enjoying the sustainable performance of their valuable resource. Companies must develop a mechanism for proper use of human capital. Corporate leaders have to shape their teams who will lead their companies in changing world. Companies and management have to come out from only payroll and other financial benefits for their valuable resource. There is a direct link in job satisfaction and performance. Companies should increase a person's working capacity and there are many techniques to increase working capacity of the employees like flexible working arrangements. This working capacity decides how he or she will successfully carry out the work in the interests of organization. Generally it is considered that working capacity is a natural occurrence of the individual's intellectual growth as time passes. Similarly, the problems which we face first time seem difficult, while the next time become easy for us.

Individuals differ in their abilities in solving the complex problems. Their capability increases in regular and predictable way. Some people grow in their jobs while others cannot. Individual's job satisfaction is fit between the problems individual facing and capacity to manage these problems. Problems increase when mismatch occur in the lives of the employees. Employees are bombarded with work and other responsibilities both at office and at home. Problems at work places and at home create mental problems for employees which decrease their productivity. For many workers, flexible working option makes job, a fun. It makes job satisfying for employees and ultimately profitable for company. The companies which do not provide such working options to their employees, employees in return do not meet the expectations of the owners. Problems steal the profits of the business and it robbing individual's prestige and self-esteem. If companies do not want their employees to fail, then they have to provide best fit between work and life. Managers provide those trainings, coaching, and mentoring which help employees for problem solving and. 
Many studies (Arthur k Y \& Berman B, 1997) show measurement of human resource effectiveness and its impact on organization. As we know business competitions escalates. All corporate resources may shrink including finance, management, and information system in changing conditions. This results into elimination and downsizing of employees, in order to save organizational resources. In such situations, managers may forget the most scare resource is employees, who can move organization from failure to a successful organization and organizations are eliminating this valuable resource. Employees want to live a happy life. The right peoples for the journey of the firm are very important. These right Employees for the journey of success of a firm need right practices first for themselves at home and also at workplaces.

Human is most valuable and a rare resource of any firm. Resource view has long roots in literature of economics and management (Ricardo, 1817, Schumpeter, 1934, Penrose, 1959). Many organizational theories (Wright PM, Mc Mahan GC \& Williams A., 1993) focus on the internal resources of firm than on external resources as a major source of the competitive advantage and success. Werner felt (1984) says, a resource is anything of firm can be a strength or weakness of that firm. These all resource other than human resources is created by human. These resources become efficient when human resource is efficient and become inefficient when human resource is inefficient. A resource is rare because of the value it has, and will deliver to any firm in achieving its goals. A rare resource like human resource has many values including, tangible and intangible values for a firm.

Employee recruitments, trainings and developments, and retention are always a challenge for firms. Selecting skilled and competitive employees for a firm is a difficult job for management. Retaining the skilled employees in the firm is even more difficult than hiring the skilled employees. In a competitive market where firm's success depends on its human resource becomes more difficult for firms. Companies with attractive packages are always in search of approaching skilled employees of other firms in the job market. Firms are ready to provide multiple benefits for skilled employees if they join them. There is no limit of benefits for able employees in any firm. These days, the firms know the value of human resource. The increased search of skilled employees for firms and social welfare has made human resource a rare resource. It has become easy for firms to find material, machinery and technology for its operations. It has become easy for firm to develop its infrastructure for its operations. Finding financial resources even has become easier than ever before for successful companies. Finding committed, hardworking and skilled human resource has become difficult for firms. These all, and many other reasons have made human resource, a rare resource.

Flexible workings are a new phenomenon for many firms especially in developing countries. Many firms have benefited from these working practices and have achieved their goals form their smart working patterns. Flexible workings include any type of arrangement which is mutually agreed between employer and employee. These include a variety of the working practices like working part times, job sharing, compressed working, working at a distance or away from working stations and flexibility in time etc. These all working patterns directly or indirectly benefit the employee. In modern working environment, these are the most liked practices in the organization by the employees and employers. The increased use and proliferation of the flexible workings is a global phenomenon. (Jacobs, Gerson \& Gornick, 2004).

\section{Integrative Model Of Flexible Workings As Valuable Resource For Firm}

Flexible workings have many benefits for a firm and employees. Flexible workings make employees more efficient, and focused during work in organization. It is most gentle way for employee treatment as it increases employee empowerment, self-esteem, willingness in working, and balancing work and life. Employees get job done according to their own working schedules and quantity they want to work. Flexible working options make variation in working hours, place for working, suitable time for working and amount of the work to be done (Kossek, E. \& Michel, J., n.d.). These practices are not only limited into variations of working but a complete package for employees.

Flexible workings are transforming working patterns by removing the constraints like time zones, place, and the quantity of the work. These working practices are considered as best working practices for employees. Employees consider it as employee friendly and employee family friendly. Availability of such practices makes an organization, employer of the choice for employees. Flexible workings directly and indirectly benefit the employer. These working practices provide employees opportunity to balance between work and family. These practices reduce work family conflict for an employee. Flexible workings increase overall quality of the life of the employee. These practices empower to employee make own working decision, own working schedule and work as he wish to work. Employees can work at home or at any other places at which he or she wants to work. Flexible working practices provide overall flexibility to employees in all dimensions of the work. A network of the relationships is given below (fig no 1) which shows how flexible workings support to employees and in return how employees benefit to organization. These working practices have become means to retain skilled employees in the organizations.. Beside value for employees these are now 
a days a management technique to manage the human resource at workplaces. These working practices have developed the concept of self-managed working teams.

There is a logical relationship between flexible workings, employee satisfaction and shareholders satisfaction. A logical and integrate model is given below (see fig no 1). The model shows how flexible workings improve the life of the employees, and how these employees benefit the organization. Flexible workings increase quality of life of the employees, provide them opportunity to balance between the work and family life, and increase employee self-esteem. These practices also empower employee to make flexibility at working. In the result of these benefits to employee, the firms gains competitive advantage, customer satisfaction, employee satisfaction and ultimate shareholders satisfaction. Integrated model of flexible workings with different benefits for employees and firm, which make flexible workings as valuable resource is given below (see figure 1).

A firm has various resources including material, machinery, land, finance and human resource. All the resources at the disposal of have their substitutes, except human resources. A lost land or machinery can be regained as these things are easily available in the market, even firms can find better than it had previously. Similarly, there are many sources of finance for any firm. Temporary loses can be converted into profits. Firms can maximize their revenues through different ways. There are many financial institutions which can provide finance to any firm on easy terms and conditions. All these resources have substitute and advantages associated with them. Human Abilities have not any substitute except itself for a firm .

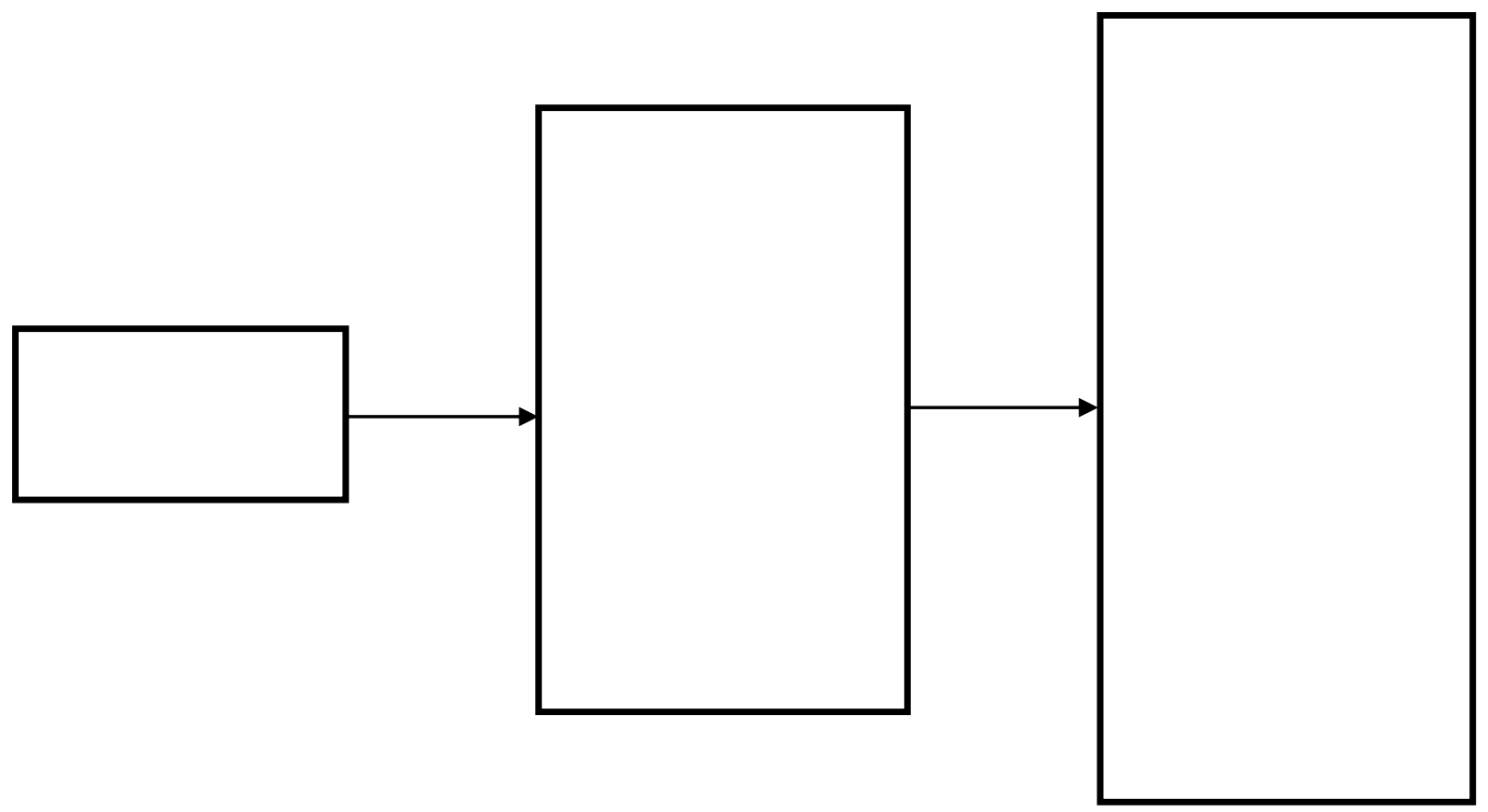

Figure 1: Integrated model of Flexible Workings

The only resource of firm that does not have its substitute is human resource. Once an employee becomes dissatisfied, and leaves the organization, there are lesser chances, he will return to the same firm. Even if the employee return, still he will not contribute as he was contributing for a firm. A lost employee will damage the image, and good will of the firm. He will carry with him all information and expertise gained. It will put firm into a long process of hiring, training, and development. There will be not any substitute of the expertise, experience and dedication of the employee for the firm. A satisfied Employee's organizational commitment will increase and there is no any substitute of this commitment.

Human resource is such resource of the firm that does not obsolete. It is not transferable and perishable. Therefore the disadvantage an employee gives a firm by leaving is not substitutable. Therefore Human resource is meeting the criteria of non-substitute, as it adds the value to firm. This value makes a firm different and a different firm in market makes different in achieving its goals. Human resource should be considered as individual but as pool of the human capital. As there is no any substitute of human resource similarly there is no any substitute of flexible working options for an employee. These options make employees' personal and professional life balanced and successful. 


\subsection{Flexible Workings}

Flexible workings are not only a management strategy to attract skilled employees but means of selfesteem, empowerment, balanced life, and quality of life for employees. Flexible working option to employees about scheduling according to their convenience is basically transforming decision making from management to employees, so that they make decisions according their own needs. It creates sense of the empowerment to employees and empowerment increases employee self-esteem, and makes working environment friendly. Empowered employees make balance in their paid and unpaid work. This creates overall flexible working environment which results in increased quality of life of the employees. The relationship between flexible workings, empowerment, work life balance, flexibility, self-esteem and quality of life is given below (see fig 2):

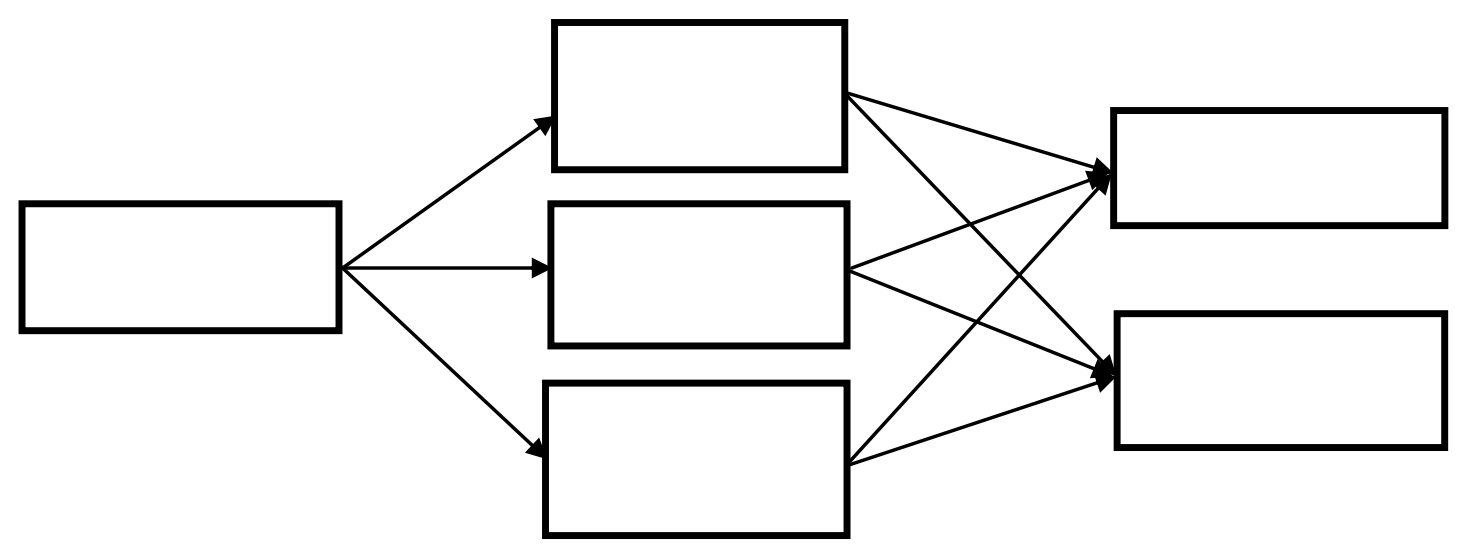

Figure 2: Employee oriented model of Flexible workings

\subsection{Employee Satisfaction}

Employee satisfaction is basically the harmony between the rewards and facilities which are given in organization and the employee's expectation about these rewards and practices. Measuring employee satisfaction at work places has different dimensions. Different dimensions of the job satisfaction can be measured separately and determining a general level of job satisfaction is one way (Rice et al, 1991, Scarpello \& Vandenberg, 1992). Flexible workings will increase empowerment at workplaces and will increase the quality of the life of the employees. These will decrease work life conflict in the life of the employee and create balance in working and personal life of the employee. In this way overall quality of the life of the employee will increase, as a result overall job satisfaction will increase. Flexible workings make work interesting, so satisfaction with work will increase. The increased job satisfaction will increase employee satisfaction. Employees' interest with physical working environment will increase. The interesting physical environment will increase the entry of the efficient and motivated employees in the organization. Many organizations are using flexible working arrangements as employee motivation tool. In modern and complex social structure, flexible workings are the most important job satisfaction tool at workplaces. Flexible workings are a base for job satisfaction and employee satisfaction at workplaces. Employee satisfaction based on flexible workings benefits may be depicted as:

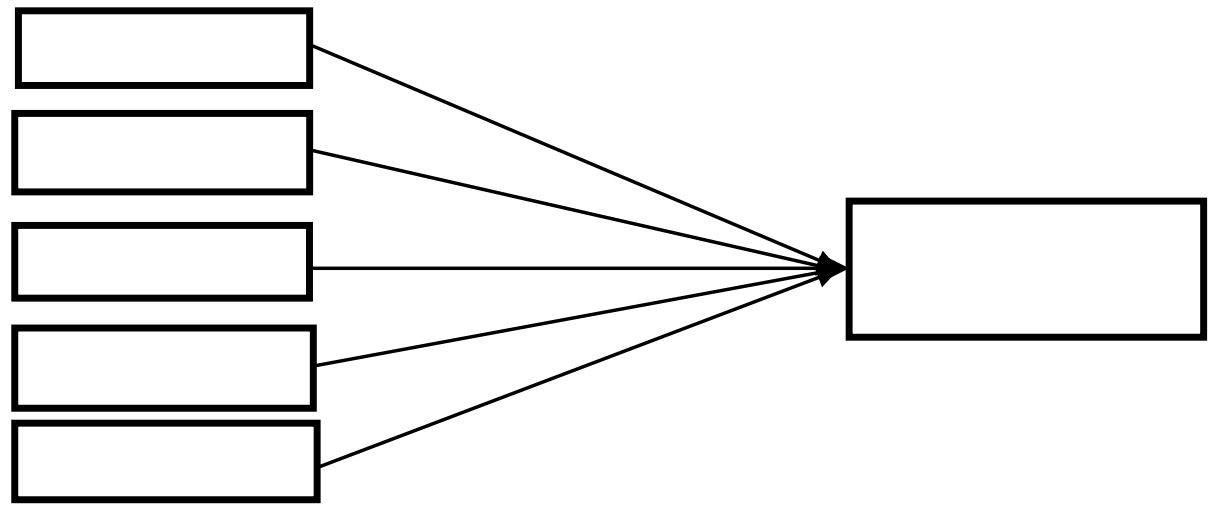


Fig 3: Flexible workings driven antecedents of Employee satisfaction

\subsection{Sustainable Competitive Advantage}

A competitive advantage for any firm is its favorable position $\mathrm{m}$ as compare to other firms in the related business. Firms becomes more competitive and profitable than its competitors and achieves its goals more successfully. It provides greater value for targeted market than other firms can provide. When this perceived value continues for longer time, or the firm is able to maintain its value over the competitors, such competitive advantage becomes sustainable, and is known as sustainable competitive advantage. This sustainable competitive advantage can be achieved through many factors including improved services, quality, reduced prices etc. The main source of this sustainable competitive advantage is human resource. The strategic management is getting growth and popularity as management's best approaches. It is recognized in the field of the management. It emphasizes a single frame work related to strengths, weakness, opportunities and threats (Barney, 1991). Strategy has become a business tool in many businesses. This strategy is a way towards business success and these developments have led towards the development of strategic management.

The new development in strategic management is resource based view for firms (Barney, 1991; Conner, 1991; Werner felt, 1984). This view is a competitive view about human resource for a firm. There is a close relationship between human resources, strategy, and performance. So competitive view is basically resource based view and this resource is human resource. Theoretical discussions (Patrick M et al , 1993 ) are not clear that which resources are sustainable competitive advantages and which resources are not competitive advantages. But this indication is much leading towards human resource as many firms consider this as most important resource. In most difficult circumstances, the firms rely only on human resources. This resource can change the circumstances for the firm from failure to success. The competitive advantages of firms are more based on the human resources as a management practices. Human resource is the most potential source of sustainable competitive advantage (Wright, Patrick M et al , 1993 ). The way in which human resource provides competitive advantage increases a firm performance. Therefore only satisfied employees create sustainable competitive advantage for a firm:

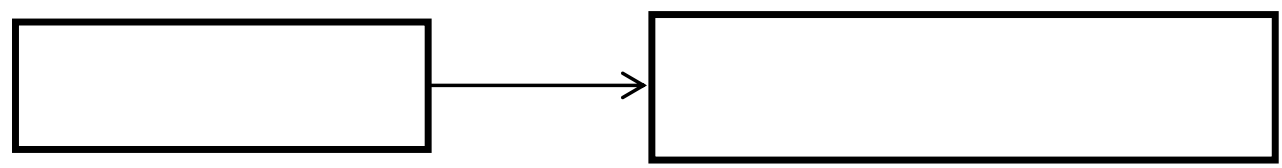

\subsection{Customer Satisfaction}

Figure 4: Consequence of Employee Satisfaction

There is an extensive evidence which shows that human resource drives the customer satisfaction. Therefore, there is need to give a careful attention to hiring process, employee trainings, motivation, and how they are treated at workplaces. Management must create and maintain a service climate in their organizations, where customer satisfaction may increase. A positive working climate has positive relationship with improved employee performance and customer satisfaction. A satisfied employee will result into satisfied customer and improved financial performance. Human resource has key role for improved market value of the firm. Management can create and sustain a working climate by its best working practices. These best practices include financial rewards, empowerment and flexible workings at workplaces. Flexible workings are considered as most employees liked practices at work place now days. This improves the employee's behavior and quality of the customers' services.

There is empirical evidence on customer satisfaction, working climate and human resource. Management has to improve this working climate for improved customer services and this climate can be improved through flexible working options in organizations. Such service businesses which have motivated and satisfied employees have more customers and satisfied than those who do not have. Positive working climate is only possible where working policies and practices are employee oriented and provide opportunity to employees to improve their own quality of life, and quality of life of their family.

Human resource can only foster and leverage positive customer services. Only employee satisfaction best way yields the customer satisfaction. Flexible workings have positive relationship with customer satisfaction. Proactive human resource leaders conclude that how employees treat customers is the result of how they are treated by management (Schneider, Benjamin \& Barbera, Karen M, 2011). If a firms wants to treat better to its customers, then it should treat in a better way to its employees. The relationship between customer satisfaction, and sustainable competitive advantage is given below (see fig $\mathbf{5}$ ): 


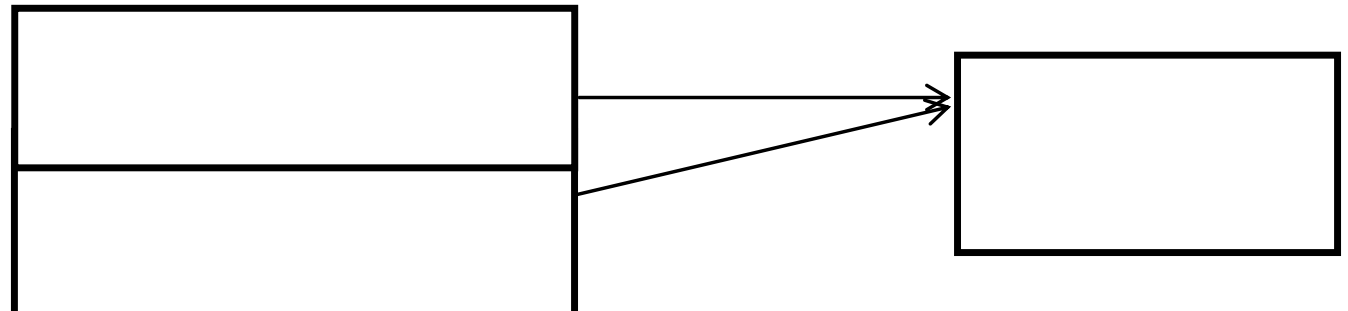

Fig 5: customer satisfaction, an indirect consequence of flexible workings

\subsection{Shareholders Satisfaction}

Shareholders being the owners of firm, are much interested in increased revenues and successful operations of firm. Increased market value and profitability is shareholders' main concern. A flexible working directly effect and benefit to employees and their life is changed because of these options at work life. Satisfied employees will satisfy the customers and increased customer satisfaction will increase revenues for the firm. These increased revenues will benefit the shareholders (Arthur k Y \& Berman B,1997. This relationship can be seen in given graph as below (see fig 6):

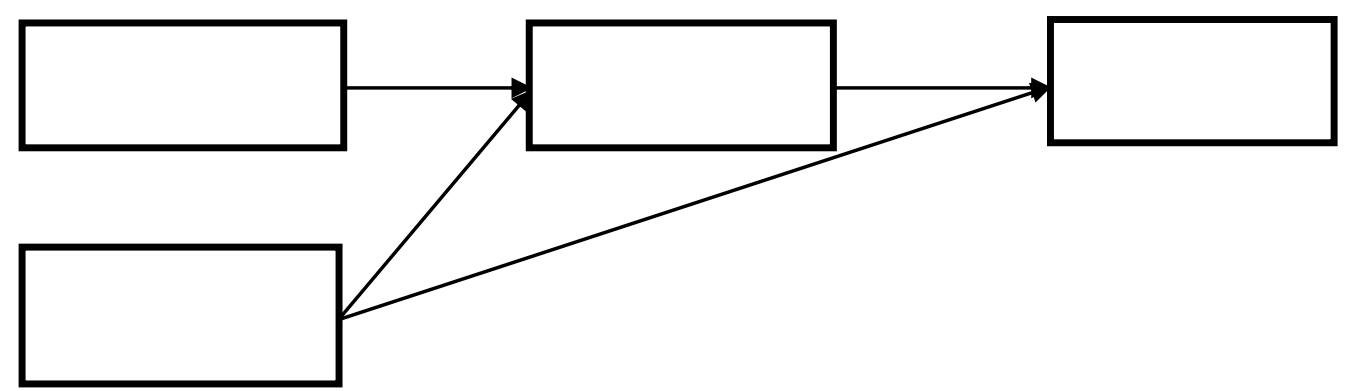

Figure 6: Antecedent conditions of shareholder satisfaction

Employee satisfaction which is because of the flexible workings options will increase customer satisfaction and increased customer satisfaction will increase shareholders' satisfaction. Flexible workings increase employee satisfaction and employee satisfaction increases shareholders satisfaction. Therefore, flexible workings increases shareholders satisfaction in any organizations. Flexible workings have become a business strategy by organizations for satisfying their shareholders. These practices increase the firm's capabilities and practices that deliver value to shareholders. Shareholders frequently ask for such policies which create value for the firms and flexible workings are the most beneficial policy to create value for firm. These practices have more return on investments; reduce administrative and human resource cost.

\subsection{Firm Sustainable Growth}

A firm's good relations with critical stakeholders lead to better performance, since the firm integrates different business and social considerations. Integrating social and business considerations creates value for the firm and stakeholders. Firm's competitive position is related to shareholders, suppliers, customers, partners, and employee satisfaction (Fonseca et al, n.d.). Flexible workings benefits for sustainable competitive advantage, employee, customer and shareholders satisfaction are key for firm's sustainable growth. This relationship is give below (see fig 7):

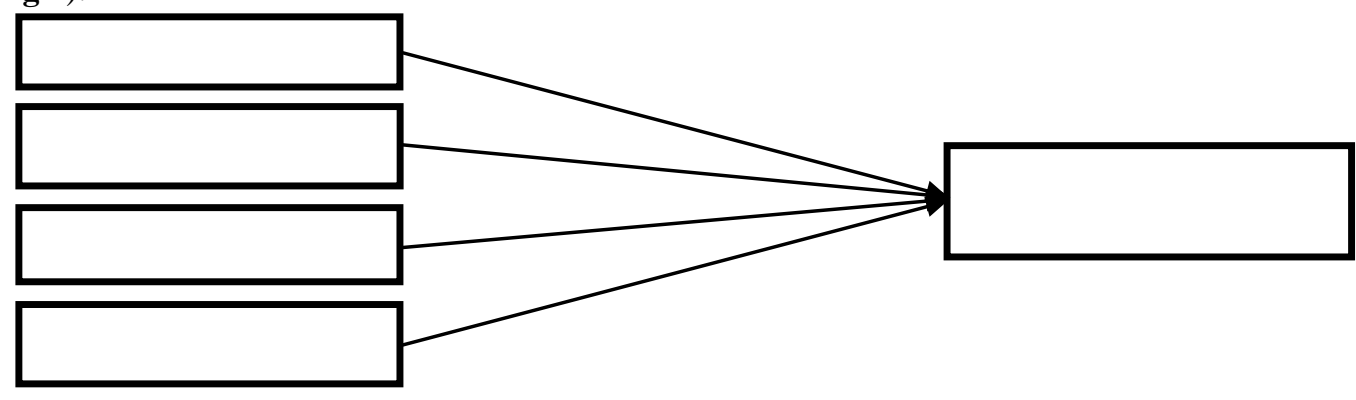


Figure 7: antecedents of Firm Sustainable Growth

\section{Conclusion}

Flexible workings increase the capabilities of human resources, and change the ways in which companies work and manage their human resource. Flexible workings not only change a management style but also change the personal and professional life of their employees. Employees in all type of the organizations most like these practices for balancing their work and life. Organizations consider human resource the most valuable resource and employees consider the flexible workings as best practices which adds value to their personal and professional life. When organizations plan for their employee satisfaction, the flexible workings are seen as the most important practices. Employers consider flexible workings as beneficial not only for employees but also for employer. As Flexible workings also save firms from a long process of hiring, trainings, and retaining the skilled employees for a firm, in a competitive job market.

Flexible workings are also important for continuity of training and development for employees. It will be very difficult for organizations in high turnover rate to continue the training and development programs for their employees. After much training and development programs employees will leave the organization. In this way improvement programs will be useless for any organization. Flexible working practices increase autonomy and empowerment at work places. Flexible workings increase the output of the employees and this increased output level of firms make a firm high performance work organization.

In changing environment, human resource plays important role for ultimate success or failure of the firm. Historically, organizational success was dependent on the search, utilization, and management of the natural resources. Now a days, success is dependent on discovering and managing human resource. Flexible workings arrangements is very important for this organizational search for skilled employees and basic element for managing the human resource. Just "feel good atmosphere", will not attract employees, but infusing the right working practices and empowerment among employs for gaining the right market value for the firm. Policies and organizational values can influence the employees' behavior. Flexible workings add the personal value to employees and employees add value to business and organizations. Providing financial rewards does not mean doing better human resource but delivering value in employees' personal and professional life, developing policies to support their families and their personal interests.

Flexible working options improve the personal life of the employees in many ways as quality of life is increased, balance between paid and unpaid work is increased, and empowerment and overall satisfaction of the employees is increased. These benefits for employees develop a sustainable competitive advantage for a firm. The firm in turn can compete with competitors. Increased employee satisfaction increases customer satisfaction which is very important for profitability and market value of the firm. These all benefits will ultimate benefit to shareholders of a firm. It is basic responsibility of management to care the interests of the shareholders. Flexible working benefits and increases satisfaction for employees, customer, and owners. Beside this, flexible workings increase sustainable competitive advantage for firm. These and many other flexible workings make these arrangements as valuable firm resource. One can argue that human mind and abilities are most valuable firm resource. The policies and programs which satisfy and motivate the most valuable resource are valuable firm resources. Flexible workings satisfy employees and satisfied employees create sustainable competitive advantage, customer and shareholders satisfaction. Sustainable competitive advantage, customer, employee, and shareholder satisfaction leads to sustainable growth.

\section{References}

[1]. Barney, J. (1991). Firm resource and sustained competitive advantage. Journal of management, 17, 99-120

[2]. Fonseca et al, (n.d.). Stakeholder Satisfaction and Sustainable Success. Business sustainability.

[3]. Hernreich, Robert. (2008). Post to Ellen Ernst Kossek, Harvard Business Press blog. http://conversationstarter.hbsp.com/2008/04/when_flextime_isnt_working.html, retrieved August 23, 2008.

[4]. Hong chee EN et al,, (2012). An Effectiveness of Human Resource Management Practices on Employee Retention in Institute of Higher learning: - A Regression Analysis International Journal of Business Research and Management (IJBRM), Volume (3) : Issue (2) : 2012

[5]. Hussain. (n.d). How HR can add value. HR Global Challenges.

[6]. Jacobs, J., Gerson, K. \& Gornick, J. (2004). In The Time Divide: Work, Family and Gender Inequality, Cambridge, Mass.: Harvard University Press.

[7]. Jacobs, J., Gerson, K. \& Gornick, J. (2004). In The Time Divide: Work, Family and Gender Inequality. Pp. 127-147, Cambridge, Mass.: Harvard University Press.

[8]. Kossek, E. \& Michel, J. In press. Flexible Work Schedules. In S. Zedeck (Ed.), APA Handbook of industrial and organizational psychology. Vol. 1, Washington, DC: American Psychological Association.

[9]. Kossek, E. and Lee, M. (2005). Making Flexibility Work: What Managers Have Learned About Implementing Reduced-Load. Alfred P. Sloan Foundation Study Technical Report

[10]. Kusku ,Fatma (2001). Dimensions of employee satisfaction: A state university example. İstanbul Technical University.

[11]. Lee ,Shinwoo .(2013). Determinants of Federal Employees' Turnover Intention across Agencies. School of Public and Environmental Affairs, Indiana University. 
[12]. M. Heathfield. (2005)Effects of pre-interview beliefs on applicant's reactions to campus interviews. Academy of Management Journal, 40(4), 947-966.

[13]. Penrose E.T. (1959). Theory of the growth of firm. New York. Wiley.

[14]. Ricardo. (1817). Principles of Political Economy and Taxation. London G. Bell.

[15]. Rice, R.W., Gentile, D.A. And Mcfarlin, D.B. (1991), Facet Importance and Job Satisfaction. Journal of Applied Psychology, 76 (1), 31-39.

[16]. Scarpello, V. And Vandenberg, R. (1992), Generalizing the Importance of Occupational and Career Views to Job Satisfaction Attitudes. Journal of Organizational Behavior, 71, 579-584.

[17]. Schneider, Benjamin \& Barbera, Karen M. (2011). Driving Customer Satisfaction through HR: Creating and Maintaining a Service Climate. Society for Industrial and Organizational Psychology.

[18]. Schumpeter, J. (1934). Theory of economic development. Cambridge. Harvard University Press.

[19]. Werner felt, B. (1984). A resource based view of the firm. Strategic management Journal.171 -180.

[20]. Wright PM, Mc Mahan GC \& Williams A. (1993). Human resource and sustained competitive advantage: a resource based perspective. Center for effective organization.

[21]. Yeung, Arthur k \& Berman Bob. (1997) Adding value through human resources: reorienting human resource measurement to drive business performance. Human Resource Management, Fall 1997, 36(3) 321-335. 